\title{
EFFECT OF DIETARY CONCENTRATE TO ROUGHAGE RATIO ON NUTRIENT DIGESTIBILITY, RUMEN FERMENTATION, GROWTH PERFORMANCE AND SERUM ACUTE PHASE PROTEIN IN GROWING BUFFALO CALVES
}

\author{
S.M. Abdel Raheem ${ }^{1}$, E.H. Hassan ${ }^{2}$ and M.M. Farghaly ${ }^{3}$ \\ ${ }^{1}$ Department of Animal Nutrition and Clinical Nutrition, Faculty of Veterinary Medicine, Assiut \\ University, Assiut, Egypt, 71526. \\ ${ }^{2}$ Department of Animal Production, Faculty of Agriculture, Al-Azhar University, Assiut, Egypt. \\ ${ }^{3}$ Department of Animal Production, Faculty of Agriculture, Assiut University, Assiut, Egypt, 71516.
}

(Received 1/6/2017, accepted 3/7/2017)

\section{SUMMARY}

\begin{abstract}
$\mathrm{T}$ his study was accomplished to designed to assess the appropriate concentrate: roughage ratio $(\mathrm{C}: \mathrm{R})$ ratio for better nutrient digestibility, rumen fermentation patterns, healthy and economic beef production in Egyptian buffalo calves. Sixteen buffalo calves aged about 18-20 months of $292.5 \pm 4.7 \mathrm{~kg}$ average body weight were randomly assigned into four groups of 4 animals each. The treatment diets were composed of four concentrate: roughage (C:R) ratios (80:20, A; 75:25, B; 60:40, C; and 55:45, D). The results revealed that increasing in the proportion of concentrate in the diet significantly $(\mathrm{p}<0.05)$ increased the digestibility of dry matter $(\mathrm{DM})$, organic matter $(\mathrm{OM})$, crude protein $(\mathrm{CP})$, crude fiber $(\mathrm{CF})$, ether extract (EE), nitrogen free extract (NFE) and the total digestible nutrients (TDN). Ruminal concentration of both volatile fatty acids (VFA) and ammonia nitrogen were increased linearly with increasing the dietary concentrate portion $(60,75$ and 80$)$, however the rumen $\mathrm{pH}$ were decreased $(\mathrm{P}<0.01)$ with increasing the concentrate level in the diet. In addition, increasing the concentrate proportion increased the dry matter intake of feed, average daily gain, final body weight; and feed cost per kg body weight. Serum, glucose, and acute phase protein were increased by increasing the dietary concentrate portion. Feeding diet containing $60 \%$ concentrate showed better performance and economic efficiency per kg body weight gain when comparing with diet containing $75 \%$ and $80 \%$ concentrates levels. This study suggested that the diet consisting of 60: 40 concentrate: roughage ratio could be considered as the optimum diet for growing buffalo calves for better performance, efficient feed utilization, economic feed efficiency and low risk of sub-acute ruminal acidosis.
\end{abstract}

Keywords: concentrate : roughage ratio, performance, subacut ruminal acidosis

\section{INTRODUCTION}

Feedlot ration should be designed to give maximum weight gain and fattening rate at the lowest cost with minimum digestive upset. Modern beef feeding requires the manipulation of concentrate to roughage ratio $(C: R)$ which affects gain and efficiency of gain. Since long time ago, there has been a tendency to fed high grain level in feedlot rations. Feeding high concentrate level improved ruminant production and decreased methan production which represent a daily feed energy losses and reduce profitability of beef production. High concentrate diet shift rumen fermentation to propionogenesis and reduce acetate and butyrate and methane production in comparison with high forage diet (Martin et al., 2010).

Many studies reported that feeding high concentrate diet to young calves with limited or no forage source (low NDF) or no optimum level of physically effective fiber could disturb rumen fermentation pattern, animal metabolism and health (Suárez et al., 2007). Concentrate diets improves animal performance, but increase the risk of rumen disorders and hepatic abscess when compared with diets with a fibre forage source due to the decrease in rumen $\mathrm{pH}$ caused by extreme consumption of fermentable carbohydrates (Nagaraja and Titgemeyer, 2007).

The dietary inclusion of concentrates for ruminant is planned to raise the energy, proteins, minerals, and vitamins content in animal diet and to improve feed utilization efficiency and productive efficiency (Morand-Fehr and Sauvant, 1987). On the other hand, long time feeding on high-concentrate diet 
predispose the animal to subacute ruminal acidosis (SARA) which described as decreased rumen $\mathrm{pH}$ under 5.6 or 5.8 as a result of excessive production of lactic acid and volatile fatty acids (VFA) (Zebeli et al., 2008 and Chen et al., 2012,). The symptoms of SARA are decreasing feed intake, decreasing rumination, and metabolic disorders and animals might live in a certain stress status (Jia et al., 2014). Subacute ruminal acidosis stimulate the release of ruminal lipopoly saccharide endotoxin and trigger an inflammatory response in steers (Gozho et al., 2005 and GonzaGonzlez et al., 2012). SARA produced by high grain diet lead to increasing the acute phase protein (APPs) in peripheral blood (Gozho et al., 2005; Khafipour et al., 2009 and Jia et al., 2014). The increased acute phase proteins (APPs) concentration is not specific for a particular disease but reflects the overall health of the animals. The information about the optimum levels of roughage in rations of fattening buffalo calves is lacking. Therefore, verifying the proper concentrate: roughage ratio is one of the most essential factors to guarantee the growth and health of buffalo calves. Consequently, the present study was designed to assess the appropriate C:R ratio for better nutrient digestibility, rumen fermentation patterns, healthy and economic beef production.

\section{MATERIALS AND METHODS}

\section{Animals, diets and management}

This study was conducted following the procedures officially approved by the Ethics Committee on Animal Experimentation of Assiut University, Faculty of veterinary medicine. This study was performed out at Research Farm of Faculty of Agriculture, Al-Azhar University Assiut, Egypt. Sixteen buffalo calves aged about $18-20$ months of $292.5 \pm 4.7 \mathrm{~kg}$ average body weight were randomly assigned into 4 groups of 4 animals each for six month fattening period. The treatment diets were composed of basal diet with four concentrate to roughage ratios $(80: 20, \mathrm{~A} ; 75: 25, \mathrm{~B} ; 60: 40, \mathrm{C}$ and 55:45, D), respectively. The experimental diet consists of concentrate mixture, wheat straw and berseem hay. The concentrates level was $2 \%$ of body weight, while roughage level was $1 \%$ of body weight. The ingredients composition and chemical analysis of experimental diets are displayed in Tables (1 and 2).

Table (1): Ingredient composition of the experimental diets.

\begin{tabular}{lllll}
\hline Item & $\mathrm{A}$ & $\mathrm{B}$ & $\mathrm{C}$ & $\mathrm{D}$ \\
\hline Concentrate mixture (\%) & 80 & 75 & 60 & 55 \\
Roughage (\%) & 20 & 25 & 40 & 45 \\
Total & 100 & 100 & 100 & 100 \\
Concentrate mixture & & & \\
Ground corn & 17 & 10.50 & 3.50 & 3 \\
Ground sorghum & 51.5 & 62.00 & 78.00 & 75.5 \\
Wheat bran & 16 & 12.00 & 2.00 & 2.00 \\
Soybean meal & 12 & 12.00 & 14 & 17 \\
Vitamin and mineral Premix & 1 & 1 & 1 & 1 \\
Limestone & 2 & 2 & 1 & 1 \\
Salt & 0.5 & 0.5 & 0.5 & 0.5 \\
Total & 100 & 100 & 100 & 100 \\
\hline *Vitamin and mineral premix each 3 kg contain: $1,250,000$ IU, Vit A; 2,500,000 IU, Vit D3; $1000 \mathrm{mg}$, Vit E; 80,000 \\
mg, Mn; 60,000 mg, Zn; 50,000 mg, iron, 20,000 mg, copper, 5000 mg, iodine, 250 mg, Se, 1000 mg, Co mg tell $3 \mathrm{~kg}$ \\
CaCO3
\end{tabular}

Preparing and mixing of diet performed daily and diets offered twice a day. Daily feed intake was noted and representative samples from feed were taken for chemical analysis. Separate pens with concrete floor equipped with locally manufactured feed manger were used for keeping each calf. Body weight of the calves were recorded initially and every month thereafter. Clean and fresh water was available ad libitum. Deworming of calves were carried out before the beginning of the experiment. 


\section{Digestibility trials}

Digestibility of feed nutrients was performed by the use of chromic oxide as indicator. The digestion trial lasted for 14 days, 7-days as preliminary period and 7 days as collection period. Exactly 10 grams of $\mathrm{Cr} 2 \mathrm{O} 3$ were hand mixed into the concentrate portion of each calf for 14 days. Orts were weighed daily, and collected before feedings of days 7-14.

Table (2): Chemical analysis and nutrient composition of experimental diets (\% on DM basis).

\begin{tabular}{lcccccc}
\hline Item & $\mathrm{A}$ & $\mathrm{B}$ & $\mathrm{C}$ & $\mathrm{D}$ & Berseem hay & Wheat straw \\
\hline Dry matter & 89.79 & 90.01 & 90.52 & 90.45 & 88.6 & 91.5 \\
ME Mcal/kg & 2.85 & 2.84 & 2.76 & 2.72 & 2.45 & 1.62 \\
Crude protein & 16.89 & 16.86 & 16.83 & 16.85 & 19.75 & 4.81 \\
Crude fiber & 10.69 & 11.86 & 15.70 & 17.29 & 30.36 & 40.87 \\
Ether extract & 3.17 & 3.06 & 2.85 & 2.80 & 2.71 & 2.19 \\
NFE & 59.36 & 62.62 & 57.71 & 55.55 & 31.72 & 43.72 \\
Ash & 9.90 & 5.60 & 6.91 & 7.51 & 15.46 & 8.42 \\
Organic matter & 90.10 & 94.40 & 93.09 & 92.49 & 84.54 & 91.58 \\
Calcium & 1.06 & 1.10 & 0.97 & 1.04 & 2.47 & 0.19 \\
Phosphorus & 0.50 & 0.45 & 0.35 & 0.34 & 0.29 & 0.05 \\
\hline
\end{tabular}

Diet $A$ with $C: R=80: 20$; diet $B$ with $C: R=75: 25$; diet $C$ with $C: R=60: 40 ;$ diet $D$ with $C: R=55: 45$

$N F E=$ Nitrogen free extract, $M E=$ Metabolizable energy

\section{Sampling and measurements}

Feed was dried at $60^{\circ} \mathrm{C}$ in a forced-air oven for 72 hours. By the end of the collection period, an equal quantity of sample was taken from each daily collection, and composited per calf to create a single sample representative of that calf's feed. About $200 \mathrm{~g}$ of fresh feces was collected by fecal grab from 7-14 days twice / 24-hr and stored in refrigerator. At the end of each period, fecal samples were thawed, composited in equal amounts by calves, and dried at $60^{\circ} \mathrm{C}$. Samples were milled to pass through a $1 \mathrm{~mm}$ screen and sealed in plastic bags. Samples were assayed for dry matter (DM), organic matter (OM), and crude protein, crude fiber $(\mathrm{CF})$, ether extract (EE) and ash according to methods defined by AOAC (1999). Chromium content of feed feces was determined by atomic absorption spectrophotometer by the methods described by Williams et al. (1962). Digestibility of nutrients were estimated according to Maynard and Loosli (1969) by the following equation:

$$
\begin{gathered}
\text { Digestibility of nutrient }(\%)=100-(100 \times(\% \text { marker in feed }) /(\% \text { marker in feces }) \times(\% \\
\text { nutrient in feces }) /(\% \text { nutrient in feed }) .
\end{gathered}
$$

\section{Blood sampling}

Blood samples were collected by jugular vein-puncture into two tubes containing either $0.1 \%$ EDTA for plasma collection or in a tube with no anticoagulant for obtaining the serum at the end of the experiment $6 \mathrm{~h}$ after the a.m. feeding. After that blood samples were centrifuged at $3000 \mathrm{rpm}$ for $20 \mathrm{~min}$ for harvesting serum and plasma and then stored at $-20 \circ \mathrm{C}$ till analyzed for blood metabolites and plasma acute phase protein. Blood metabolites (glucose, total protein, albumin, AST, ALT and blood urea nitrogen) were analyzed by spectrophotometer (Unico, USA) using commercial test kits according to manufacturer company.

\section{Determination of acute phase proteins}

Serum haptoglobin (Hp) concentration was determined using a commercial sandwich ELISA (GenWay Biotech Inc. San Diego, CA). Samples were diluted (50-time dilution). Intra and inter-assay CV were $3.3 \%$ and $11 \%$, respectively. Serum amyloid A was determined by the use of commercial multispecies ELISA (Tridelta Development Ltd, Kildare, Ireland) explained by McDonald et al. (1991).

\section{Rumen liquor parameters}

In the last day of collection period at $3 \mathrm{~h}$ post morning feeding rumen liquor was taken from each calf by stomach tube. A double layer of cheesecloth was used for filtration of rumen liquor into plastic tubes $(50 \mathrm{ml})$. A portable $\mathrm{pH}$ meter (Beckman, model 45, USA) was used for determination of $\mathrm{pH}$ immediately after sampling. Rumen liquor was used to determine total volatile fatly acids (VFA) concentration 
according to method described by Cannon et al. (2010). Rumen fluid samples was mixed with oxalic acid $(0.1 \mathrm{~mol} / \mathrm{l})$, sodium azide $(40 \mathrm{mmol} / \mathrm{l})$ and capronic acid $(0.1 \mathrm{mmol} / \mathrm{l})$ as internal standard, centrifuged and the supernatant was analyzed for short chain fatty acids (SCFAs) by gas chromatography (Agilent $6890 \mathrm{~N}$ GC) equipped with a $30 \mathrm{~m} \times 530 \mu \mathrm{m} \times 0.1 \mu \mathrm{m}$ capillary column with flame ionization detector according to the method. While rumen ammonia nitrogen $(\mathrm{NH} 3-\mathrm{N})$ concentration $\mathrm{mg} / 100 \mathrm{ml}$ was analyzed according to (method 973.49, AOAC International, 2000).

\section{Statistical analysis}

SPSS program version 16.0 software (SPSS, 2008) was used for analysis of raw data, Differences between groups in nutrient digestibility, rumen fermentation, blood metabolites; serum acute phase protein and performance were estimated by one-way ANOVA. Duncan's multiple range tests (Duncan, 1955) was used to detect the differences between means. The data were tabulated in mean \pm S.E.M. Level of significance was set at $\mathrm{P}<0.05$.

\section{RESULTS AND DISCUSSION}

\section{Nutrients digestibility}

The data in Table (3) indicated that increasing the proportion of concentrate in the diet significantly (p $<0.05$ ) increased the digestibility of DM, OM, CP, CF, EE and NFE. Similarly, the percentage of digestible crude protein (DCP), and total digestible nutrients (TDN) were significantly increased in high concentrate diets (A, B and C) in comparison with diet D. This result was coincided with the findings observed by previous investigation carried out by Cantalapiedra-Hijar et al. (2009), Saini et al., (2012), Kumari et al., (2012), Ma et al. (2014) and Malisetty et al. (2014). The decrease in nutrient digestion at $80 \%$ concentrate level may be produced by the inhibition of cellulolytic bacteria growth caused by decreasing the rumen $\mathrm{pH}$ under 6.2 (Grant and Mertens, 1992).

Table (3): Effect of concentrate to roughage ratio on nutrient apparent digestibility, \% .

\begin{tabular}{|c|c|c|c|c|c|}
\hline \multirow[b]{2}{*}{ Item } & \multicolumn{4}{|c|}{ Treatment } & \multirow[b]{2}{*}{$P$} \\
\hline & $\mathrm{A}$ & $\mathrm{B}$ & $\mathrm{C}$ & $\mathrm{D}$ & \\
\hline & \multicolumn{4}{|c|}{ Diet digestibility } & \\
\hline DM & $69.86^{\mathrm{b}} \pm 0.35$ & $73.2^{\mathrm{a}} \pm 0.43$ & $73.47^{\mathrm{a}} \pm 0.31$ & $68.54^{\mathrm{b}} \pm 0.68$ & $<0.001$ \\
\hline $\mathrm{OM}$ & $71.42^{\mathrm{c}} \pm 0.14$ & $75.44^{\mathrm{b}} \pm 0.21$ & $76.03^{a} \pm 0.14$ & $70.62^{\mathrm{d}} \pm 0.12$ & $<0.001$ \\
\hline $\mathrm{CP}$ & $71.31^{b} \pm 0.34$ & $76.34^{\mathrm{a}} \pm 0.7$ & $76.11^{\mathrm{a}} \pm 0.31$ & $69.86^{\mathrm{c}} \pm 0.44$ & $<0.001$ \\
\hline $\mathrm{CF}$ & $65.66^{\mathrm{b}} \pm 0.21$ & $68.28^{\mathrm{a}} \pm 0.25$ & $68.42^{\mathrm{a}} \pm 0.27$ & $64.02^{\mathrm{c}} \pm 0.6$ & $<0.001$ \\
\hline $\mathrm{EE}$ & $68.59^{\mathrm{b}} \pm 0.1$ & $71.43^{\mathrm{a}} \pm 0.29$ & $71.64^{\mathrm{a}} \pm 0.22$ & $66.68^{c} \pm 0.27$ & $<0.001$ \\
\hline NFE & $74.19^{b} \pm 0.15$ & $\begin{array}{l}76.87^{\mathrm{a}} \pm 0.24 \\
\text { Nutritive value }\end{array}$ & $77.26^{\mathrm{a}} \pm 0.08$ & $73.32^{c} \pm 0.17$ & $<0.001$ \\
\hline DCP, $\%$ & $12.04^{\mathrm{b}} \pm 0.06$ & $12.87^{\mathrm{a}} \pm 0.05$ & $12.81^{\mathrm{a}} \pm 0.05$ & $11.77^{\mathrm{c}} \pm 0.07$ & $<0.001$ \\
\hline TDN, $\%$ & $67.99^{c} \pm 0.1$ & $74.02^{\mathrm{a}} \pm 1.9$ & $72.73^{\mathrm{b}} \pm 0.08$ & $67.77^{\mathrm{c}} \pm 0.13$ & $<0.001$ \\
\hline
\end{tabular}

Means within row bearing different superscripts differ significantly $(p<0.05)$.

Diet $A$ with $C: R=80: 20$; diet $B$ with $C: R=75: 25$; diet $C$ with $C: R=60: 40$ and diet $D$ with $C: R=55: 45$

$D M$ dry matter, OM organic matter, CP crude protein, EE ether extract, NFE, nitrogen free extract, DCP digestible crude protein, TDN total digestible nutrients and SE starch equivalent.

\section{Rumen properties}

The rumen fermentation parameters were exhibited in Table (4). The C:R ratio affected $(\mathrm{P}<0.05)$ ruminal $\mathrm{pH}, \mathrm{VFA}$ and ammonia- $\mathrm{N}$ concentration. There was a significant $(\mathrm{P}<0.05)$ decrease in the rumen $\mathrm{pH}$ in the buffalo calves by increasing the level of concentrate from 55 to $80 \%$. In the current study increasing concentrate in diets was increased $(\mathrm{p}<0.01)$ rumen total volatile fatty acids and ammonia nitrogen concentration. This result support the finding of previous studies performed by CantalapiedraHijar et al. (2009), Agle et al. (2010) and Van Dung et al. (2014). The higher rumen volatile fatty acid produced from feeding high concentrate diet decreased $(\mathrm{P}<0.01)$ rumen $\mathrm{pH}$ as compared with high roughage diet. This observation supports the finding of Cantalapiedra-Hijar et al. (2009). The greater lactic acid produced from the greater amount of starch present in high concentrate diet was the main 
reason for the reduction in rumen $\mathrm{pH}$ (Slyter, 1976). The higher rumen ammonia $\mathrm{N}$ in high concentrate diet may be caused by the higher digestibility of crude protein in high concentrate diet because the rumen ammonia nitrogen depend up on the protein content in the diet and the digestibility of protein (Cantalapiedra-Hijar et al., 2009).

Table (4): Effect of concentrate to roughage ratio on rumen fermentation parameters.

\begin{tabular}{lccccc}
\hline & \multicolumn{5}{c}{ Treatment } \\
\cline { 2 - 5 } Item & $\mathrm{A}$ & $\mathrm{B}$ & $\mathrm{C}$ & $\mathrm{D}$ & $P$ \\
\hline $\mathrm{nyyyyn} \mathrm{pH}$ & $6.08^{\mathrm{b}} \pm 0.07$ & $6.31^{\mathrm{a}} \pm 0.1$ & $6.44^{\mathrm{a}} \pm 0.03$ & $6.49^{\mathrm{a}} \pm 0.03$ & 0.009 \\
$\mathrm{NH} 3-\mathrm{N}, \mathrm{mg} / \mathrm{dl}$ & $14.72^{\mathrm{a}} \pm 0.14$ & $13.08^{\mathrm{b}} \pm 0.22$ & $11.17^{\mathrm{c}} \pm 0.04$ & $11.46^{\mathrm{c}} \pm 0.05$ & $<0.001$ \\
Acetate, $\mathrm{m} M$ & $52.23^{\mathrm{a}} \pm 0.32$ & $50.01^{\mathrm{b}} \pm 0.62$ & $47.74^{\mathrm{c}} \pm 0.32$ & $45.91^{\mathrm{d}} \pm 0.07$ & $<0.001$ \\
Propionate, $\mathrm{m} M$ & $6.04^{\mathrm{b}} \pm 0.05$ & $6.13^{\mathrm{a}} \pm 0.01$ & $6.05^{\mathrm{b}} \pm 0.01$ & $5.85^{\mathrm{c}} \pm 0.02$ & $<0.001$ \\
Iso butyrate, $\mathrm{m} M$ & $5.00^{\mathrm{c}} \pm 0.11$ & $5.84^{\mathrm{b}} \pm 0.07$ & $5.74^{\mathrm{b}} \pm 0.13$ & $6.38^{\mathrm{a}} \pm 0.02$ & $<0.001$ \\
Butyrate, $\mathrm{m} M$ & $4.8^{\mathrm{c}} \pm 0.03$ & $5.83^{\mathrm{b}} \pm 0.53$ & $7.53^{\mathrm{a}} \pm 0.31$ & $6.01^{\mathrm{b}} \pm 0.02$ & $<0.001$ \\
Isovalerate, $\mathrm{m} M$ & $4.76^{\mathrm{a}} \pm 0.01$ & $4.58^{\mathrm{b}} \pm 0.07$ & $4.06^{\mathrm{d}} \pm 0.01$ & $4.37^{\mathrm{c}} \pm 0.02$ & $<0.001$ \\
Valerate, $\mathrm{mM}$ & $3.09^{\mathrm{a}} \pm 0.02$ & $2.87^{\mathrm{b}} \pm 0.05$ & $2.55^{\mathrm{d}} \pm 0.01$ & $2.78^{\mathrm{c}} \pm 0.01$ & $<0.001$ \\
Total VFAs, $\mathrm{m} M$ & $75.94^{\mathrm{a}} \pm 0.29$ & $75.29^{\mathrm{ab}} \pm 0.22$ & $73.68^{\mathrm{b}} \pm 0.51$ & $70.32^{\mathrm{c}} \pm 0.97$ & $<0.001$ \\
A:P & $8.65^{\mathrm{a}} \pm 0.08$ & $8.23^{\mathrm{b}} \pm 0.11$ & $7.79^{\mathrm{c}} \pm 0.04$ & $7.84^{\mathrm{c}} \pm 0.02$ & $<0.001$ \\
\hline
\end{tabular}

Means within row bearing different superscripts differ significantly $(p<0.05)$.

Diet A with $C: R=80: 20$; diet $B$ with $C: R=75: 25$; diet $C$ with $C: R=60: 40$; and diet $D$ with $C: R=55: 45$ $\mathrm{mM}$ millimolar or $\mathrm{mmol} / \mathrm{L}$.

\section{Blood metabolites}

The blood metabolites were displayed in Table (5). Blood metabolites are crucial tools for general health state and vitality. In this study, we noticed that increasing the proportion of concentrate from $55 \%$ to $80 \%$ in diets increased blood glucose, total protein and globulin concentration in buffalo calves. The increase in plasma glucose concentration reflects higher hepatic glucogenesis (Bobe et al., 2004), associated with the higher propionate proportion observed in our study. This result support the previous report of Serment et al. (2011). Abonyi et al. (2013), Chen et al. (2015) and Dong et al. (2017) who revealed that the high concentrate diet probably improved energy balance, protein synthesis and humoral immunity of the animal. Blood urea nitrogen (BUN) concentration was used as indicator of nitrogen utilization efficiency by ruminants (Lewis, 1957). Blood urea nitrogen (BUN) was not affected $(\mathrm{P}>0.05)$ by different concentrate to roughage ratio in this study. The urea $\mathrm{N}$ produced from protein and amino acid catabolism in the body. That implies decreasing protein utilization, increasing blood urea $\mathrm{N}$ content (Ponnampalam et al., 2005). Experimental diets with different C: R ratios failed to induce any impact on liver enzymes (ALT and AST).

Table (5): Effect of concentrate to roughage ratio on blood metabolites.

\begin{tabular}{|c|c|c|c|c|c|}
\hline \multirow{2}{*}{ Item } & \multicolumn{4}{|c|}{ Treatment } & \multirow{2}{*}{$P$} \\
\hline & $\bar{A}$ & $\bar{B}$ & $\mathrm{C}$ & $\bar{D}$ & \\
\hline Glucose (mg/dl) & $64.10^{\mathrm{a}} \pm 0.41$ & $62.26^{b} \pm 0.28$ & $59.95^{\mathrm{c}} \pm 0.14$ & $58.04^{\mathrm{d}} \pm 0.21$ & $<0.001$ \\
\hline Total protein, $\mathrm{g} / \mathrm{dl}$ & $7.52^{a} \pm 0.09$ & $7.44^{\mathrm{a}} \pm 0.04$ & $7.01^{\mathrm{b}} \pm 0.01$ & $6.99^{\mathrm{b}} \pm 0.09$ & $<0.001$ \\
\hline Albumin $(\mathrm{g} / \mathrm{dl})$ & $4.44^{\mathrm{ab}} \pm 0.04$ & $4.52^{\mathrm{a}} \pm 0.02$ & $4.51^{\mathrm{a}} \pm 0.02$ & $4.42^{b} \pm 0.01$ & 0.04 \\
\hline Globulin (g/ dl) & $3.08^{\mathrm{a}} \pm 0.07$ & $2.92^{\mathrm{a}} \pm 0.05$ & $2.49^{\mathrm{b}} \pm 0.11$ & $2.57^{\mathrm{b}} \pm 0.09$ & $<0.001$ \\
\hline $\mathrm{Al} /$ Glo ratio & $1.44^{\mathrm{b}} \pm 0.03$ & $1.54^{\mathrm{b}} \pm 0.02$ & $1.83^{\mathrm{a}} \pm 0.09$ & $1.74^{\mathrm{a}} \pm 0.07$ & $<0.001$ \\
\hline $\operatorname{ALT}(\mathrm{U} / \mathrm{l})$ & $30.1 \pm 1.9$ & $25.21 \pm 0.94$ & $30.77 \pm 1.38$ & $28.11 \pm 2.44$ & 0.11 \\
\hline $\mathrm{AST}(\mathrm{U} / \mathrm{l})$ & $78.16 \pm 0.17$ & $78.2 \pm 0.18$ & $78.32 \pm 0.05$ & $78.36 \pm 0.04$ & 0.69 \\
\hline Cholesterol (mg/dl) & $89.32^{\mathrm{ab}} \pm 0.29$ & $88.48^{\mathrm{ab}} \pm 0.42$ & $94.1^{\mathrm{b}} \pm 0.91$ & $99.19^{\mathrm{a}} \pm 0.99$ & $<0.001$ \\
\hline BUN (mg/dl) & $25.82 \pm 0.09$ & $25.78 \pm 0.04$ & $25.76 \pm .08$ & $25.56 \pm 0.14$ & 0.291 \\
\hline
\end{tabular}

Means within row bearing different superscripts differ significantly $(p<0.05)$.

$B U N=$ Blood urea nitrogen .

Diet $A$ with $C: R=80: 20$; diet $B$ with $C: R=75: 25$; diet $C$ with $C: R=60: 40$ and diet $D$ with $C: R=55: 45$. 


\section{Serum acute phase proteins}

Variation in the ratio between concentrate to roughage induced significant $(\mathrm{P}<0.01)$ effects on serum acute phase proteins as clear in Table (6). There were significant increase $(\mathrm{P}<0.001)$ in serum haptoglobulin, serum amyloid $\mathrm{A}$ and serum $\mathrm{C}$ - reactive protein by increasing the dietary concentrate portion. These results in line with the results of Gozho et al. (2005), Khafipour et al. (2009) and Plaizier et al. (2009). Although serum acute phase protein increased with high concentrate diet and the risk of subclinical or subacute ruminal, acidosis was increased but the greater risk of acidosis did not impair growth performance in buffalo calves under present experimental station.

Table (6): Effect of concentrate to roughage ratio on levels of serum acute phase proteins.

\begin{tabular}{lccccc}
\hline \multirow{2}{*}{ Item } & \multicolumn{4}{c}{ Treatment } & \\
\cline { 2 - 5 } & $\mathrm{A}$ & $\mathrm{B}$ & $\mathrm{C}$ & $\mathrm{D}$ & $\mathrm{P}$ \\
\hline Haptoglobulin, $\mu \mathrm{g} / \mathrm{ml}$ & $41.66^{\mathrm{a}} \pm 0.87$ & $41.07^{\mathrm{a}} \pm 0.25$ & $39.52^{\mathrm{b}} \pm 0.18$ & $36.61^{\mathrm{c}} \pm 0.27$ & $<0.0001$ \\
Serum amyloid $\mathrm{A}, \mu \mathrm{g} / \mathrm{ml}$ & $35.66^{\mathrm{a}} \pm 0.87$ & $35.07^{\mathrm{a}} \pm 0.25$ & $33.52^{\mathrm{b}} \pm 0.18$ & $30.61^{\mathrm{c}} \pm 0.28$ & $<0.0001$ \\
C-reactive protein, $\mathrm{mg} / \mathrm{L}$ & $38.65^{\mathrm{a}} \pm 0.87$ & $38.07^{\mathrm{a}} \pm 0.25$ & $32.52^{\mathrm{b}} \pm 0.17$ & $29.61^{\mathrm{c}} \pm 0.28$ & $<0.0001$ \\
\hline
\end{tabular}

Means within row bearing different superscripts differ significantly $(p<0.05)$.

Diet $A$ with $C: R=80: 20$; diet $B$ with $C: R=75: 25$; diet $C$ with $C: R=60: 40$ and diet $D$ with $C: R=55: 45$.

\section{Growth performance}

Performance of buffalo calves was presented in Table (7). Feeding high concentrate significantly increased final body weight, total and daily body weight gain and dry matter intake. In addition, feeding high concentrate diet to buffalo calves induced higher feed conversion rate diet (Diet A and B) when compared with low concentrate diet (C and D). Furthermore, low concentrate diets (60 and $55 \%)$ are cheaper in cost in comparison with high concentrate diet (80 and $75 \%)$. The improvement of growth performance with high concentrate diet was in agreement with previous work of Haddad, (2005), Papi et al. (2011), Chen et al. (2015) and Rashid et al. (2015). The increase in dry matter intake in high concentrate diet (A and B) could be ascribed to the higher palatability of high concentrate diet (Ma et al., 2014). Higher roughage diets reduced production costs in comparison with higher concentrate diets as well in our trial. In this respect Norris et al. (2002) mentioned that crossbred males fed with high concentrate diet had better $(P<0.05)$ feed conversion rate than that of those fed with medium and low concentrate diets. From economical point of view, calves fed with diet $\mathrm{C}$ were economically efficient than that of those on diet A and B. The feed cost required for $1 \mathrm{~kg}$ LWG increased with the increase of concentrate level in diet. This is in line with results of Helal et al. (2011) who demonstrated that feed cost for one $\mathrm{kg}$ weight gain increased with the increase in concentrate level (15\% to $100 \%)$ in buffalo and steers, respectively.

Table (7): Performance of buffalo calves fed experimental diets.

\begin{tabular}{|c|c|c|c|c|c|}
\hline \multirow{2}{*}{ Item } & \multicolumn{4}{|c|}{ Treatment } & \multirow{2}{*}{$P$} \\
\hline & $\mathrm{A}$ & $\mathrm{B}$ & $\mathrm{C}$ & $\mathrm{D}$ & \\
\hline Initial weight, $\mathrm{kg}$ & $292.75 \pm 3.35$ & $292.5 \pm 4.69$ & $296.0 \pm 3.49$ & $295.00 \pm 2.16$ & 0.87 \\
\hline Final weight, kg & $432.5^{\mathrm{a}} \pm 1.04$ & $430.25^{\mathrm{a}} \pm 2.28$ & $428.5^{\mathrm{a}} \pm 0.64$ & $419.75^{\mathrm{b}} \pm 0.85$ & $<0.001$ \\
\hline BWG gain, $\mathrm{kg}$ & $139.75^{\mathrm{a}} \pm 3.71$ & $137.75^{\mathrm{a}} \pm 3.79$ & $132.5^{\mathrm{ab}} \pm 3.59$ & $124.75^{\mathrm{b}} \pm 2.78$ & 0.04 \\
\hline Daily gain, $\mathrm{kg}$ & $0.932^{\mathrm{a}} \pm 0.03$ & $0.918^{\mathrm{a}} \pm 0.03$ & $0.883^{\mathrm{ab}} \pm 0.02$ & $0.831^{\mathrm{b}} \pm 0.01$ & 0.04 \\
\hline DMI of concentrate & $6.11^{\mathrm{a}} \pm 0.01$ & $5.28^{\mathrm{b}} \pm 0.01$ & $4.46^{\mathrm{c}} \pm 0.03$ & $4.00^{\mathrm{d}} \pm 0.02$ & $<0.001$ \\
\hline DMI of roughage & $1.53^{\mathrm{d}} \pm 0.02$ & $2.26^{\mathrm{c}} \pm 0.004$ & $2.97^{b} \pm 0.02$ & $3.28^{\mathrm{a}} \pm 0.02$ & $<0.001$ \\
\hline Total DM intake $\mathrm{kg} /$ day $^{¥}$ & $7.64^{\mathrm{a}} \pm 0.01$ & $7.54^{\mathrm{a}} \pm 0.01$ & $7.44^{b} \pm 0.05$ & $7.28^{\mathrm{c}} \pm 0.04$ & $<0.001$ \\
\hline$* \mathrm{FC} \mathrm{kg} \mathrm{DM} / \mathrm{kg}$ gain & $8.22 \pm 0.22$ & $8.24 \pm 0.23$ & $8.44 \pm 0.27$ & $8.77 \pm 0.24$ & 0.38 \\
\hline Feed cost/day E.P.** & $31.85^{\mathrm{a}} \pm 0.03$ & $29.09^{\mathrm{b}} \pm 0.05$ & $26.32^{c} \pm 0.17$ & $24.62^{\mathrm{d}} \pm 0.14$ & $<0.01$ \\
\hline Feed cost $/ \mathrm{kg} \mathrm{BWG***}$ & $34.25^{\mathrm{a}} \pm 0.95$ & $31.75^{\mathrm{ab}} \pm 0.90$ & $29.88^{\mathrm{b}} \pm 0.96$ & $29.66^{\mathrm{b}} \pm 0.81$ & 0.01 \\
\hline
\end{tabular}

Means within row bearing different superscripts differ significantly $(p<0.05)$.

Diet $A$ with $C: R=80: 20$; diet $B$ with $C: R=75: 25$; diet $C$ with $C: R=60: 40$ and diet $D$ with $C: R=55: 45$

$* F C=$ Feed conversion ratio, $¥ D M I=$ Dry matter intake, $* *$ E.P. $=$ Egyptian pound, $* * * B W G=$ Body weight gain. 


\section{CONCLUSION}

The optimum levels of concentrate to roughage ratio in rations of fattening buffalo calves is very important factor affecting feed utilization and the whole ruminant production capacity. This study suggested that the diet consisting of 60: 40 concentrate: roughage ratio could be considered as the optimum diet for growing buffalo calves for better performance, efficient feed utilization, economic feed efficiency and low risk of sub-acute ruminal acidosis.

\section{REFERENCES}

Abonyi, F. O., N. S. Machebe, M. S. Ezea, J. I. Eze, B. C. Omeke and B. N. Marire. (2013). Effects of substituting soya bean meal (SBM) with blood meal (BM) on biochemical profile of pregnant pigs. Trop. Anim. Health Prod. 45:957-963.

Agle, M., Hristov A. N. , S. Zaman, C. Schneider, P. M. Ndegwa and V. K. Vaddella (2010). Effect of dietary concentrate on rumen fermentation, digestibility, and nitrogen losses in dairy cows. J. Dairy Sci. $93: 4211-4222$.

AOAC (1999). Association of Official Analytical Chemists. Official Methods of Analysis, 16th ed.: AOAC, Gaithersburg, MD, USA.

AOAC (2000). Official Methods of Analysis. 17th ed. AOAC International, Arlington, VA.

Bobe, G., J. W. Young and D. C. Beitz. (2004). Pathology, etiology, prevention, and treatment of fatty liver in dairy cows. J. Dairy Sci., 87:3105-3124.

Cannon, S.J., G.C. Fahey Jr., L.L. Pope, L.L. Bauer, R.L. Wallace, B.L. Miller and J.K. Drackley (2010). Inclusion of psyllium in milk replacer for neonatal calves. 2. Effects on volatile fatty acid concentrations, microbial populations and gastrointestinal tract size. J. Dairy Sci., 93 , 4744-4758.

Cantalapiedra-Hijar, G., D.R. Yáñez-Ruiz, A.I. Martín, García and E. Molina-Alcaide (2009). Effects of forage: concentrate ratio and forage type on apparent digestibility, ruminal fermentation and microbial growth in goats. J. Anim. Sci. 87, 622-631.

Chen, Y., Oba M. and L. L. Guan (2012). Variation of bacterial communities and expression of Toll-like receptor genes in the rumen of steers differing in susceptibility to subacute ruminal acidosis. Vet. Microbiol. 159:451-459.

Chen G.J., S.D. Song, B.X. Wang, Z.F. Zhang, Z.L. Peng, C.H. Guo, J.C. Zhong, and Y. Wang (2015). Effects of forage : concentrate ratio on growth performance, ruminal fermentation and blood metabolites in housing-feeding Yaks. Asian Australas. J. Anim. Sci. 28 (12) : 1736-1741

Dong L. F., W. B. Zhang, N. F. Zhang, Y. Tu and Q. Y. Diao (2017). Feeding different dietary protein to energy ratios to Holstein heifers: effects on growth performance, blood metabolites and rumen fermentation parameters. Journal of Animal Physiology and Animal Nutrition 101 (2017) 30-37.

Duncan, D.B. (1955). Multiple range and multiple F test. Biometrics, 11:1-42.

Gonzáleza L.A., X. Mantecab, S. Calsamigliab, K.S. Schwartzkopf-Gensweinc and A. Ferretb (2012). Ruminal acidosis in feedlot cattle: Interplay between feed ingredients, rumen function and feeding behavior (a review). Animal Feed Science and Technology 172, 66- 79.

Gozho, G., J. Plaizier, D. Krause, A. Kennedy and K. Wittenberg (2005). Subacute ruminal acidosis induces ruminal lipopolysaccharide endotoxin release and triggers an inflammatory response. Journal of Dairy Science 88, 1399-1403.

Grant, R. J. and D. R. Mertens (1992). Influence of buffer $\mathrm{pH}$ and raw corn starch addition on in vitro fiber digestion kinetics. J. Dairy Sci. 75:2762-2768.

Haddad, S.G. (2005). Effect of dietary forage: concentrate ratio on growth performance and carcass characteristics of growing Baladi kids. Small Ruminant Research, 57: 43-49. 


\section{Abdel Raheem et al.}

Helal, F. I. S., K. M. Abdel-Rahman, B. M. Ahmed and S. S. Omar (2011). Effect of feeding different levels of concentrates on buffalo calves performance, digestibility and carcass traits. AmericanEurasian Journal of Agriculture and Environmental Science, 10 (2): 186-92.

Jia, Y. Y., S. Q. Wang, Y. D. Ni, Y. S. Zhang, S. Zhuang and X. Z. Shen (2014). High concentrateinduced subacute ruminal acidosis (SARA) increases plasma acute phase proteins (APPs) and cortisol in goats. Animal, 8:9: 1433-1438.

Khafipour E, D. Krause and J. Plaizier (2009). A grain-based subacute ruminal acidosis challenge causes translocation of lipopolysaccharide and triggers inflammation. Journal of Dairy Science 92, 10601070.

Kumari, N.N., Y.R. Reddy, M. Blummel, D. Nagalakshmi, K. Sudhakar, V.R. Reddy, T. Monika, M. Pavani, M.S. Reddy, B.V.S. Reddy and C.R. Reddy (2012). Effect of roughage to concentrate ratio of sweet sorghum (Sorghum biclor L. Moench) bagasse-based complete diet on nutrient utilization and microbial N supply in lamb. Tropical animal health and production 44 (7), 1717-1724.

Lewis, D. (1957). Blood-urea concentration in relation to protein utilization in the ruminant. Journal of Agricultural Science 48, 438.

Ma T., K.D. Deng, Y. Tua, N.F. Zhang, C.G. Jiang, J. Liu, Y.G. Zhao and Q.Y. Diao (2014). Effect of dietary forage-to-concentrate ratios on urinary excretion of purine derivatives and microbial nitrogen yields in the rumen of Dorper crossbred sheep. Livestock Science 160, 37-44.

Malisetty, V., R.R. Yerradoddi, N. Devanaboina, M. Mallam and P. Mitta (2014). Effect of feeding sorghum straw based complete rations with different roughage to concentrate ratio on dry matter intake, nutrient utilization, and nitrogen balance in Nellore ram lambs. Trop Anim Health Prod 46, 759-764.

Martin, C., D. Morgavi and M. Doreau (2010). Methane mitigation in ruminants: from microbe to the farm scale. Animal 4, 351-365.

Maynard, L.A. and J.K. Loosli (1969). Animal Nutrition, 6th ed. McGraw-Hill, New York, USA.

McDonald, T.L., A. Weber and J.W. Smith (1991). A monoclonal antibody sandwich immunoassay for serum amyloid (SAA) protein. J. Immunol. Methods 144: 149-155.

Morand-Fehr, P. and D. Sauvant (1987). Feeding strategies in goats. Pages 1275-1303 in Proc. 4th Int. Conf. Goats, Brasilia, Brazil. (Eds. O. P. Santana, A. G. da Silva, and W. C. Foote). Depto. De Difusao de Tecnol., Brasilia, Brazil.

Nagaraja, T.G. and E.C. Titgemeyer (2007). Ruminal acidosis in beef cattle: the Current microbiological and nutritional outlook. Journal of Dairy Science 90 (E. suppl.), E17-E38.

Norris, D., J. Macala, J. Makore and B. Mosimanyana (2002). Feedlot performance of various breed groups of cattle fed low to high levels of roughage. Livestock Research for Rural Development, 14(6). Accessed March 25, 2015. http://www.lrrd.org/lrrd14/6/norr146.htm.

Papi, N., A. Mostafa-Tehrani, H. Amanloub and M. Memarianb (2011). Effects of dietary forage-toconcentrate ratios on performance and carcass characteristics of growing fat-tailed lambs. Animal Feed Science and Technology 163: 93-98.

Plaizier, J.C., D.O. Krause, G.N. Gozho and B.W. McBride (2009). Subacute ruminal acidosis in dairy cows: the physiological causes, incidence and consequences. Veterinary Journal 176 (1), 21-31.

Ponnampalam, E.N., A.R. Egan, A.J. Sinclair and B.J. Leury (2005). Feed intake, growth, plasma glucose and urea nitrogen concentration, and carcass traits of lambs fed isoenergetic amounts of canola meal, soybean meal and fish meal with orange based diet. Small Rumin. Res. 58, 245-252.

Rashid, M.M., S. Khan Huque, M.A. Hoque, N.R. Sarker and A.F. Haque Bhuiyan (2015). Effect of Concentrate to Roughage Ratio on Cost Effective Growth Performance of Brahman Crossbred Calves. Journal of Agricultural Science and Technology A 5, 286-295.

Saini, J.K., J.S. Hundal, M. Wadhwa and M.P.S. Bakshi (2012). Effect of roughage to concentrate ratio in the diet on the rumen environment and nutrient utilization in goat and sheep. Indian J. Anim. Nutr. 29 (4): 333-337 
Serment, A., P. Schmidely, S. Giger-reverdin, P. Chapoutot and D. Sauvant (2011). Effects of the percentage of concentrate on rumen fermentation, nutrient digestibility, plasma metabolites and milk composition in mid-lactation goats. J. Dairy Sci. 94 :3960-3972

Slyter, L.L. (1976). Influence of acidosis on rumen function. J. Anim. Sci. 43:910-929.

SPSS (2008). Statistical package for the social science, Release 16, SPSS INC, Chicago, USA.

Suárez, B.J., C.G. van Reenen, N. van Stockhofe, J. Dijkstra and W.J.J. Gerrits (2007). Effect of roughage source and roughage to concentrate ratio on animal performance and rumen development in veal calves. J. Dairy Sci. 90, 2390-2403.

Van Dung, D., W. Shang, and W. Yao (2014). Effect of Crude protein levels in concentrate and concentrate levels in diet on in vitro fermentation. Asian Australas. J. Anim. Sci. 27 (6), 797-805.

Williams, C. H., D.J. David and O. Iismaa, (1962). The determination of chromic oxide in fecal samples by atomic absorption spectroscopy. J. Agric. Sci. 59, 381-385.

Zebeli, Q., J. Dijkstra, M. Tafaj, H. Steingass, B.N. Ametaj and W. Drochner (2008). Modeling the adequacy of dietary fiber in dairy cows based on the responses of ruminal $\mathrm{pH}$ and milk fat production to composition of the diet. J. Dairy Sci., 91, 2046-66.

تأثير نسبة العلف المركز الي العلف الخشن في العليقة على الهضم وتخمر الكرش وأداء النمو وبروتينات

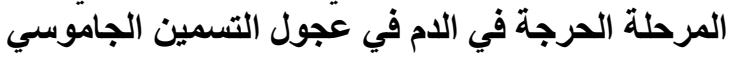

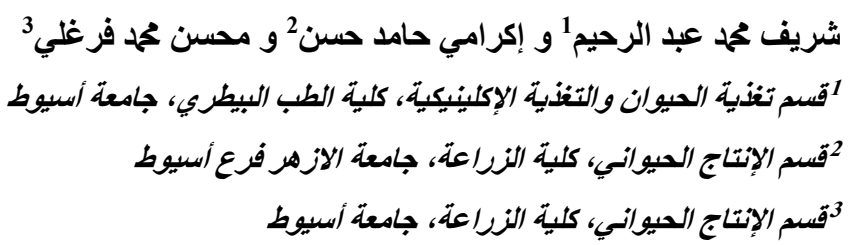

صُُمت هذه الدراسة لمعرفة تأثير نسبة العلف المركز الي العلف الخشن في العليقة على الهضم وتخمر الكرش وبروتينات المرحلة

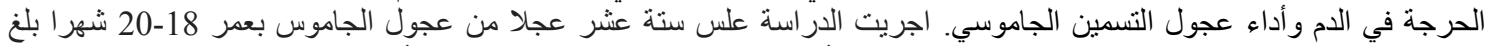

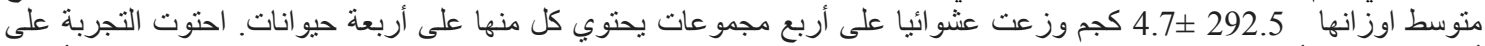
أربع معاملات بأربع نسب مختلفة للعلف المركز الي العلف الخشن (202:80،

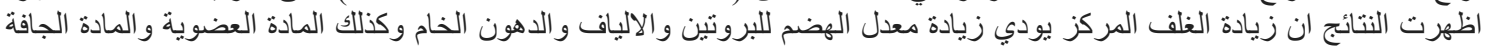

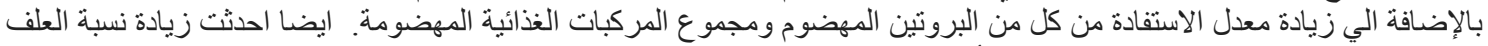

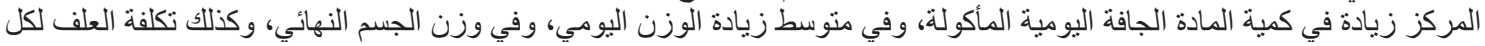

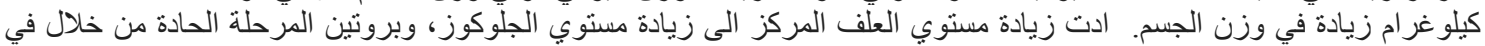

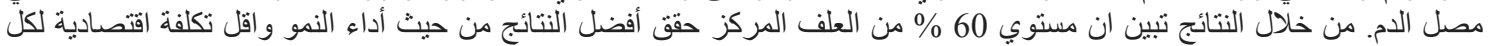

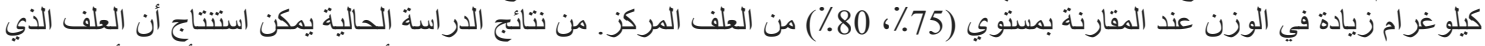

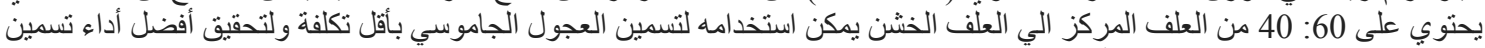

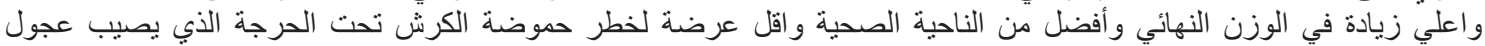

